\title{
The Husserl-Heidegger Relationship in the Jewish Imagination
}

\section{Introduction}

On one of the walls in the Raphael Rooms in the Vatican hangs the fresco Scuola di Atene by the Italian Renaissance artist after whom the rooms are named. Staged in the vanishing point of the fresco, amidst numerous renowned figures of the ancient world, stand Plato and Aristotle, holding their famous works the Timaeus and Nichomachean Ethics. In a subtle but brilliant signal, Raphael captured the two philosophers diverging views: Plato's finger points upwards, towards the heavens, where the eternal forms of which he theorized reside, while Aristotle's hand motions downwards, towards the concrete realm of earth, illustrating his empiricist and practical concerns. With this artistic touch, Raphael symbolically immortalized the philosophical contrast between Plato the teacher and Aristotle the pupil.

The history of philosophy has known a handful of truly exceptional relationships between teacher and student. Even less have assumed symbolic significance. Yet in terms of the fruitfulness of its relationship, the intensity of its break, and the tragic drama of its historical circumstances, seemingly few compare to the troubled relationship between Edmund Husserl and Martin Heidegger.

Much has been written on the personal and intellectual vicissitudes of these renowned phenomenologists. In the present essay I address an overlooked perspective and examine how this relationship was registered in the Jewish imagination, predominantly in Germany and Palestine. My argument is that the rise and fall, succession and break, inheritance and betrayal, contribution and misuse that marks this relationship resonated in a specific way with twentieth century European Jewish experiences, and was retold accordingly. It should be stated from the outset that I have no pretense to offer a comprehensive reception-history of the Husserl-Heidegger relation. Rather, I trace how different narratives and typologies of twentieth century European Jewish existence are absorbed in the retelling of Husserl's life and his charged personal and philosophical relationship with Heidegger. Stated otherwise, I wish to establish that various ideological tendencies concerning modern Judaism and Jewishness have been projected onto the Husserl-Heidegger relationship. To demonstrate that the reception of these two philosophers was wider and richer than often acknowledged in critical scholarship, I pay particular attention to less-known figures who are outside the accepted 'canon' of twentieth century Jewish thought. 


\section{Husserl and Heidegger: Personal Ties and Philosophical Horizons}

It is best to begin with a few biographical points concerning their personal and philosophical relationship. ${ }^{1}$ Heidegger first encountered Husserl's writings on the phenomenological method in 1909, as a theology student at Freiburg University who was disturbed by traditional ontological questions. They began corresponding in 1914, and in mid-1916, when Husserl moved to Freiburg, they met and gradually drew closer. By 1919 Heidegger was made Husserl's assistant and quickly assumed the status of his protégé and "one true student". ${ }^{2}$ At one point, Husserl is said to proclaim to Heidegger - "you and I are die Phänomenologie!"3 It would seem that this fondness was mutual according to Karl Löwith's testimony, Heidegger would typically address Husserl in his letters as "fatherly friend". ${ }^{4}$ Yet we now know that Heidegger dissented from Husserl's phenomenological approach already in his first lecture course in 1919, and he continued to develop his contesting methodology throughout his time in Freiburg (1919-1923) and Marburg (1923-1928). ${ }^{5}$ There are indications that Heidegger did not entirely hide his disagreements from Husserl, though he may have minimized them in front of his master. As a whole, a certain ambiguity characterized Heidegger's attitude towards Husserl. In the beginning of his 1923 lecture course, "Ontology: The Hermeneutics of Facticity", for example, he recognized his debt by remarking that "Husserl opened my eyes". ${ }^{6}$ Yet in the same year he wrote to Löwith: "I am now convinced that Husserl was never a philosopher, not even for one second in his life". ${ }^{7}$ Husserl, for his part, constantly and actively supported Heidegger's various attempts to secure a permanent academic post. He helped Heidegger secure the post at Marburg and find a publisher for Sein und Zeit, and he also orchestrated that it would be Heidegger who would inherit his chair in philosophy at Freiburg upon his retirement.

\footnotetext{
1 This abridged presentation is indebted to Thomas Sheehan, "Husserl and Heidegger: The Making and Unmaking of a Relationship", Edmund Husserl, Psychological and Transcendental Phenomenology and the Confrontation with Heidegger, (1927-1931), eds. and trans. T. Sheehan and R. Palmer (Dordrecht, 1997), 1-32. My thanks are extended to Thomas Sheehan for reading and commenting on an earlier draft of this article, and to Ted Kisiel for the information he provided. Unless indicated otherwise, the translations from Hebrew and German in the present essay are my own.

2 In a letter to Alexander Pfänder, January 6, 1931, trans. B. C. Hopkins, Husserl, Psychological and Transcendental Phenomenology, 480.

${ }^{3}$ Dorion Cairns, Conversation with Husserl and Fink (The Hague, 1976), 9.

${ }^{4}$ Karl Löwith, My Life in Germany Before and After 1933: A Report, trans. E. King (London, 1994), 59.

5 Analysis of these lecture courses can be found in Theodore Kisiel, The Genesis of Heidegger's Being and Time (California, 1995).

${ }^{6}$ Martin Heidegger, Ontologie (Hermeneutik der Faktizität), Gesamtausgabe, vol. 63 (Frankfurt am Main, 1988), 5. Henceforth GA. In English: Heidegger, Ontology - The Hermeneutics of Facticity, trans. J. van Buren (Bloomington, 1999$), 4$.

${ }^{7}$ Sheehan, "Husserl and Heidegger", 17.
} 
In 1926, for Husserl's sixty-seventh birthday, Heidegger granted him a copy of the publisher's manuscript of his incomplete work Sein und Zeit, bearing the dedication "to Husserl in friendship and admiration". However, this personal gesture could not cover up the deeply ambiguous judgment of Husserl's philosophy that is reflected in this work. On the one hand, Sein und Zeit bears some clear continuities with Husserl's work. First and foremost, Heidegger, like Husserl, is a phenomenologist; both thinkers aim, as much as possible, to suspend predetermined judgments and theories in their observations and pay close attention to how phenomena show up meaningfully to us through our direct experience. In contrast to the Marburg neo-Kantian perspective, which begins its analysis from the 'fact of science', both agree that any philosophical effort to approach objects, insofar as they are manifest and meaningful, must begin with our pre-scientific or pre-theorizing everyday experience. As Husserl put it to Leo Strauss, "the Marburg school begins with the roof, while I begin with the foundation". ${ }^{8}$ On the other hand, Sein und Zeit also challenges some of Husserl's most fundamental philosophical assumptions. After all, for Husserl in Ideas (1913), phenomenology is a transcendental theory of knowledge aiming to describe the eidetic structures of consciousness. While beginning from our common understanding of the world, phenomenology for Husserl requires a 'transcendental phenomenological reduction', a bracketing or suspending of our 'naïve', everyday attitude towards objects (including the question of their existence), followed by a reduction of our concentration to the object itself as it appears in our perception, and drawing from the object's particular manifestation the essential structures of 'pure' consciousness which constitutes it. As an investigation into what is essential, Husserlian phenomenology's imperative is objectivity and a-temporal truth. Driving Husserl's project is the conviction that philosophy is strenge Wissenschaft, and for him, this meant that it bears a particular moral task. For this reason, he spoke of the humanistic "responsibility we have to mankind" in reaching true, scientific conclusions, bearing "the stamp of eternity".

In the introduction to Sein und Zeit Heidegger wrote that "the following would not have been possible if the ground had not been prepared by Edmund Husserl”, but he immediately clarified that it is not in the "actuality" of Husserl's program, but only in the possibilities it opened. ${ }^{10}$ Heidegger objected to the abstract and theoretical orientation governing Husserl's analytic, and the Husserlian rationalist intentional acts of a detached, abstract 'pure consciousness' gives way to the practical and

\footnotetext{
${ }^{8}$ Leo Strauss, "Philosophy as Rigorous Science”, Studies in Platonic Political Philosophy (Chicago, 1983$) 31$.

${ }^{9}$ Husserl, "Philosophy as Rigorous Science", trans. M. Brainard, The New Yearbook for Phenomenology and Phenomenological Philosophy, II (2002): 249-95.

${ }^{10}$ Martin Heidegger, Being and Time, trans. J. Macquarrie and E. Robinson (New York, 2008), 62.
} 
unmediated engagement with an already meaningful world of an irreducible, historically situated, factical and finite Dasein. Phenomenology should not depart from the concrete lived human experience towards a 'transcendental subjectivity'; it is, for Heidegger, no longer a method for philosophizing, but philosophy itself. Moreover, with an eye to Husserl, Heidegger assured that Dasein's attunement to the world, its moods, are central to the way entities are disclosed. For this reason, he saw it necessary to investigate the being of Dasein as the appropriate way into his main philosophical objective - the ontological question of being (though his focus on Dasein led to the prevalent misattribution of his philosophy as existentialism). There is, for him, no stepping outside the cave, as it were, to a context-free and disengaged perspective, to pure presence, to presuppositionless and a-temporal truths. This unrealizable aspiration, shared, according to Heidegger, by both NeoKantianism and Husserlian phenomenology (and much of traditional philosophy as a whole), is a fantasy enabled by long-standing and ill-conceived philosophical presumptions regarding comprehension, hermeneutics, truth, and being. Heidegger's aim, thus, is to constructively dismantle this tradition and provide an alternative way of thinking to traditional metaphysics and Western humanism.

Around the time of Sein und Zeit's publication, Heidegger wrote to Karl Jaspers: "if the treatise has been written 'against' anyone, then it has been written against Husserl'. ${ }^{11}$ That it constituted a break from Husserl's phenomenology was recognized by many. The young Gilbert Ryle, in one of Sein und Zeit's first reviews, affirmed that "Heidegger's project was certainly not what Husserl meant by phenomenology, and perhaps it wasn't even phenomenology at all". ${ }^{22}$ After a close study of Heidegger's book, Husserl understood this himself. "I came to the conclusion", he wrote, "that his 'phenomenology' has nothing to do with mine and that I view his pseudo-scientificity as an obstacle [Hemmnis] to the development of philosophy". ${ }^{13}$ In public lectures and a review of Heidegger's work, Husserl attacked what he saw as a profound distortion of his phenomenological analytic and its ideal of strenge Wissenschaft. ${ }^{14}$ Yet this damning judgment was more than just a philosophical critique. Husserl's correspondences at the time reveal his pain that his students, and above all Heidegger, "this

\footnotetext{
${ }^{11}$ Letter to Jaspers, December 26, 1926, The Heidegger-Jaspers Correspondence (1920-1963), eds. W. Biemel and H. Saner, trans. G. E. Aylesworth (New York, 2003), 73.

12 Gilbert Ryle, "Martin Heidegger: 'Sein und Zeit”, Mind, vol. 38, no. 151 (July, 1929): 355-70.

${ }^{13}$ Letter to Dietrich Mahnke, from January 8, 1931, Edmund Husserl, Briefwechsel, band III: Die Göttinger Schule, ed. K. Schuhmann (Dordrecht, 1994), 473. In English, Sheehan, "Husserl and Heidegger", 29-30.

${ }^{14}$ Cf. Husserl, "Phenomenology and Anthropology", in Husserl, Psychological and Transcendental Phenomenology, 485-500.
} 
natural power of a genius", did not follow his path. ${ }^{15}$ Indeed, the philosophical fallout came alongside a deterioration in their personal relations. Emmanuel Levinas, who attended both philosopher's lectures in the late 1920s, later testified that the students were very much aware of their teachers' feud, but "on the basis of texts that were read and compared. Not on the basis of facts". ${ }^{16}$ Husserl's disappointment with Heidegger's lack of redactional effort as editor of the manuscript of his 19041905 lectures on 'Phenomenological Time', and a failed attempt to write together an article on phenomenology for the Encyclopedia Britannica, are two better-known incidents reflecting how the personal intermingled with the philosophical. ${ }^{17}$ But perhaps the best illustration of this is found in a marginal remark Husserl penned opposite to Heidegger's handwritten dedication on his copy of Sein und Zeit, attributed to Aristotle: 'Amicus Plato, magis amica veritas' ['Plato is my friend, but a greater friend is the truth']. ${ }^{18}$

The publication of Heidegger's masterpiece made the philosophical rift between the two phenomenologists public and apparent. In 1931 Husserl wrote to Alexander Pfänder: "How I may stand scientifically to Heidegger I have plainly expressed at every opportunity. There is now gossip enough, and my personal disappointment with Heidegger, etc., is nobody else's business". ${ }^{19}$ Quickly, however, the unraveling of their personal relationship very much became a public matter. On January 30, 1933, Hitler was appointed chancellor of Germany. In April, Husserl, who had converted to Christianity decades before but qualified as a Jew according to Nazi standards, was forced to take a 'leave of absence' from his retired position at the University. He was soon after fired, together with all active and retired Jewish professors in German universities, and all his academic privileges were cancelled. Like so many of those who were affected by this decree, Husserl, a patriotic German nationalist whose son Wolfgang was killed as a German soldier in the Great War, was crushed.

And coinciding with Husserl's downfall was Heidegger's ascent. Heidegger became the Nazisponsored rector of the Freiburg University on April 22, 1933, and he joined the party shortly after,

\footnotetext{
${ }^{15}$ Letter to Roman Ingarden on December 26, 1927, in Husserl, Psychological and Transcendental Phenomenology, 384.

${ }^{16}$ Is it Righteous to Be? Interviews with Emmanuel Levinas, ed. J. Robbins (Stanford, 2001), 37.

${ }^{17}$ See also, among many: Walter Biemal, "Erinnerungsfragmente", Erinnerung an Martin Heidegger, ed. G. Neske (Pfullingen, 1977), 15-24; Steven Galt Crowell, “Does the Husserl/Heidegger Feud Rest on a Mistake?”, Husserl Studies, 18, (2002):12340; Idem, "Heidegger and Husserl: The Matter and Method of Philosophy", Blackwell Companion to Heidegger, eds. H. Dreyfus and M. Wrathall (Oxford, 2005), 49-64; Hugo Ott, Martin Heidegger: A Political Life, trans. A. Blunden (London, 1993), 17286.

18 Sheehan, "Husserl and Heidegger", 30.

${ }^{19}$ Husserl, Psychological and Transcendental Phenomenology, 480.
} 
on May 3. It is unclear exactly when Heidegger's sympathies to Hitler began, but it seems that around 1932 (if not earlier) he began voicing his political views, which included occasional anti-Semitic remarks, more openly. ${ }^{20}$ His address on the occasion of his inauguration, "The Self-Assertion of the German University", was perceived by many as a public ratification of the Party's ideology, as it made use of rhetoric associated with the Nazis. Precisely how to understand Heidegger's Rektoratsrede and what exactly he envisioned the National Socialist movement to be when he joined its ranks has been the subject of heated debates ever since. What is uncontestable, however, is that he remained a member of the party until 1945, that his tenure as rector of the university was short - it came to an end a year later, in April of 1934 - and most significantly for our purpose, that Husserl's dismissal took place under his watch as rector. It is almost certain that Heidegger had no direct hand in these occurrences, but it is also the case that he did not - and perhaps could not - intervene.

From Husserl's side, this dire episode was ever more painful because it involved Heidegger, who ignored his plight. His deep sense of betrayal is conveyed in letter to his pupil Dietrich Mahnke from May 4-5, 1933: "thanks to a national law, valid henceforth and forever, we are no longer to have the right to call ourselves Germans. Our intellectual achievements will no longer be part of German intellectual history. They will only survive branded with the mark 'Jewish' - which by all accounts the new regime is determined to make a scar of disdain - and as a poison that German intellectuals must guard themselves against, a virus that must be eradicated". ${ }^{21}$ This letter aptly conveys Husserl's understanding that he has been expelled not only from his university, but from the German nation of which he considered himself a proud son. He was no longer a German - he was a Jew. In this letter, Husserl also registered his repulsion for Heidegger's open embracement of the Nazi party and his "anti-Semitism, which he came to express with increasing vigor".

The question of Husserl's Jewish identity will occupy us below at length. Here, however, it should be noted that Heidegger was hardly ignorant of Husserl's Jewish origins. In a letter to Hannah Arendt from the winter of 1932/3, responding to her inquiry over rumors of his antisemitism, Heidegger invoked his relationship with Husserl, alongside Georg Misch and Ernst Cassirer, as evidence refuting these "slanders". ${ }^{22}$ In 1939 he would somewhat loosely couple what he considered

${ }^{20}$ Cf. Husserl's letter to Landgrebe, dated May 28, 1932, where he notes that "Heidegger has yielded to National Socialism and blunt anti-Semitism", in Husserl Briefwechsel, band IV: Die Freiburger Schüler, ed. K. Schuhmann (Dordrecht, 1994), 289.

${ }^{21}$ Husserl, Briefwechsel, band III, 492. In English: Becoming Heidegger: On the Trail of His Early Occasional Writings, 1910-1927, eds. T. Kisiel and T. Sheehan (Evanston, Illinois, 2007), 413.

22 Hannah Arendt and Martin Heidegger, Letters, 1925-1975 (Florida, 2004), 52-3. 
to be Husserl's philosophical limitations and his Jewishness, the one in some way reflecting on the other. ${ }^{23}$ The conspicuous fact, that throughout the 1920s and early 1930s Heidegger was practically surrounded by Jews - not only his teachers, but the majority of his closest and most talented students were of Jewish background, like Arendt herself - is one we cannot discuss at present. Unsurprisingly, after the Nazis took over, these close encounters with Jews led to suspicions. As Löwith later reported, "the petty-bourgeois orthodoxy of the party was suspicious of Heidegger's National Socialism insofar as Jewish and racial considerations played no role. Sein und Zeit was dedicated to the Jew Husserl, his Kant-book to the half-Jew Scheler, and in his courses at Freiburg, Bergson and Simmel were taught". ${ }^{24}$ Husserl's misfortune, at any rate, continued. In 1936 his name was officially removed from the Freiburg University faculty lists, and, publicly denounced, he was prohibited from publishing any more works in Germany. ${ }^{25} \mathrm{Ill}$ and ostracized, Husserl died in 1938. Heidegger did not visit Husserl throughout the entire time, nor did he attend his funeral. He would later apologize for this, calling it "a human failure" in a letter to Mrs. Husserl. ${ }^{26}$

Many of the facts about the troubled personal relation between Husserl and Heidegger came to light only recently, and there is still much that remains unknown. Yet from the very beginning, rumors of Heidegger's mistreatment of Husserl dispersed. Word traveled of Heidegger's neglect of Husserl in time of need, epitomized by his absence from his former mentor's funeral. Another stubborn rumor circulated: that as the Nazi-appointed rector, Heidegger had banned Husserl from using the university's library. Hugo Ott, Heidegger's biographer, claimed that Heidegger's complaint that "the allegation that as rector I banned Husserl from the University and the library is a particularly vile calumny", is justified. "So how did the story about Heidegger banning Husserl from the library come about?", Ott asked - "I simply don't know". ${ }^{27}$ Yet the 'library story' spread fast and became common knowledge in philosophical circles. Moreover, that Heidegger agreed to the publisher's request to remove the dedication to Husserl from the 1941 edition of Sein und Zeit further manifested his impaired attitude towards his teacher (although other mentions of Husserl, including openly

\footnotetext{
${ }^{23}$ Heidegger, Pondering XII-XV: Black. Notebooks 1939-1941, trans. Richard Rojcewicz (Bloomington, 2017), 37. And see Peter Trawny, Heidegger and the Myth of a Jewish World Conspiracy, trans. Andrew J. Mitchell (Chicago, 2015), 55-63.

${ }^{24}$ Cf. Löwith, My Life in Germany, 41-2.

${ }^{25}$ Karl Schuhmann, Husserl-Chronik: Denk- und Lebensweg Edmund Husserls (Den Haag, 1977), 472. And see also Malvine Husserl, "Skizze eines Lebensbilds von Edmund Husserl", ed. K. Schuhmann, Husserl Studies, 5 (1988): 105-25.

${ }^{26}$ Heidegger, "Nur noch ein Gott kann uns retten," Der Spiegel 30, May 31, 1976. Cf. Heidegger, "Brief an Malvine Husserl zum 90. Geburstag", dated March 6, 1950, GA 16, 443.

${ }^{27}$ Ott, Martin Heidegger, 172-86.
} 
positive ones, remained unchanged). In the eyes of many, the maltreatment of Husserl and the open embrace of Hitler confirmed Heidegger's dubious personal reputation. Indeed, the objections to the value of his philosophy by virtue of Heidegger's compromised moral character that have been voiced with tenacity since the publication of his so-called Black Notebooks are hardly new. One of the harsher pronouncements in this regard was uttered by Karl Popper, who stated late in his life: "I appeal to the philosophers of all countries to unite and never again mention Heidegger or talk to another philosopher who defends Heidegger. This man was a devil. I mean, he behaved like a devil to his beloved teacher, and he has a devilish influence on Germany." ${ }^{28}$ Likewise, Gilbert Ryle allegedly remarked: "Heidegger? Bad man; must be a bad philosopher". Arendt even accused her former professor of being a "potential murderer [potentiellen Mörder]", since, she suggested, Husserl's discharge so deeply saddened him that it ultimately precipitated his death. ${ }^{29}$

\section{The Question of Husserl's Jewishness}

With this background, we now turn to examine how the personal and philosophical relationship of these two men was perceived, imagined, retold, and utilized in Jewish contexts. I argue that a number of readily present formalistic oppositions animated the way in which the HusserlHeidegger relationship was imagined: Husserl embraced the ultimacy of reason, while Heidegger rejected it. Husserl preached the value of rigorous science, while Heidegger spoke of moods and expressionism. Husserl was a humanist, while Heidegger opposed humanism as byproduct of a corrupt metaphysics. Husserl strived for essences and truth, while Heidegger propounded relativism and nihilism. Husserl perceived himself as bearing the torch of the Western philosophical tradition spanning back from Plato in antiquity, through Descartes, and running up to his own days, while Heidegger, in contrast, saw this entire tradition as thought gone array, a history which he was anointed to 'destruct'. Husserl believed in the moral task of philosophy, while Heidegger harnessed his philosophical talents to the ruinous force of National Socialism. And of course, Husserl was of Jewish descent, who was persecuted by the ultra-nationalist German regime to which Heidegger pledged alliance.

It should be stated immediately that many of these contrasts are schematic, misconstrued, and even outright wrong; and the presentation of one philosopher as the complete counter-image of the

\footnotetext{
${ }^{28}$ Quoted in Eugene Yue-Ching Ho, Intellectus, 23 (1992): 1-5.

${ }^{29}$ Hanna Arendt, Karl Jaspers, Correspondence, ed. L. Kohler and H. Saner, trans. by R. and R. Kimber (San Diego, 1992$), 48$. Arendt later retracted her accusation and renewed her ties with Heidegger.
} 
other is oversimplified. Not only is Heidegger's relation to National Socialism complicated, he is also much more indebted to Husserl than he would be willing to admit, and recent publications of Husserl's Nachlass, especially his Crisis of the European Sciences Sciences and Transcendental Phenomenology, have shown that later on, Husserl took not-insignificant strides towards Heidegger's perspective, like the introduction of the notion of 'life-world'. ${ }^{30}$ Indeed, as we shall see, the clear-cut, structuralist and almost ad-hominem edifice of the depictions of the Husserl and Heidegger relation is problematized when it clashes with a frequent tendency to admit to Heidegger's philosophical superiority. And yet the forceful antipodal image that emerges played a considerable role in the way this relationship was imagined.

Now, too, it is best to begin with a brief biographical sketch, this time of Husserl's religious trajectory. Edmund Husserl was born on April 8, 1859, in Prossnitz, Moravia, a region of the Austrian Empire that was soon to become part of Czechoslovakia. ${ }^{31}$ Prossnitz was a town rich in Jewish history. Boasting a Jewish presence since the mid-fifteenth century, it was historically a center of Jewish learning that raised and attracted many Jewish rabbis, teachers and scholars - most prominently, perhaps, Rabbi Moses Sofer, known as ha-@hatam Sofer. Husserl was born into a middle class, nonorthodox Jewish household. The language he likely heard at home was Yiddish. His upbringing took place in a generally Jewish context, and as a child his fellow classmates were all Jews. From the age of ten, his family's financial resources allowed the young Husserl to attend better schools outside Prossnitz where he received a secular education. It appears that Husserl had little familiarity with traditional Jewish learning and did not know Hebrew. After army service he studied mathematics in Leipzig and then in Berlin, and following the recommendation of Thomas Masaryk, he attended philosophy lectures by Franz Berntano. Encouraged by Masaryk, a devout Christian, Husserl began reading the New Testament daily during this time. ${ }^{32}$ In the 'Vita' he submitted to the Philosophy Faculty of the University of Vienna (dated July 13, 1882), where he then studied, he wrote, somewhat

\footnotetext{
${ }^{30}$ Merleau-Ponty would later argue that the worldly-hermeneutic orientation brought to bear by Heidegger is an internal rather than external impulse in Husserl's phenomenology. See also Rudolph Bernet, Iso Kern and Eduard Marbach, An Introduction to Husserlian Phenomenology (Evanston, Ill., 1993); Dan Zahavi, Husserl's Phenomenology (Stanford, 2003); Dermot Moran, Edmund Husserl: The Crisis of the European Sciences and Transcendental Phenomenology: An Introduction (Cambridge, 2012). 31 Cf. Jan Kühndel, "Edmund Husserls Heimat und Herkunft", Archiv für Geschichte der Philosophie 51 (1969):286-90; Bohuslav Eliás, "Die Judenstadt von Prostejov und die Familie Husserl (Einege Bemerkungen)", Zur Problematik der transzendentalen Phänomenologie Edmund Husserls (Prague, 1988), 234-9; Idem, "Zur Geschichte der Israelitengemeinde von Prostèjov (Proßnitz)", Husserl Studies, 10 (1994):237-48; Edmund Husserl und die phänomenologische Bewegung: Zeugnisse in Text und Bild, ed. H. R. Sepp (Freiburg and München, 1988), 119-20.

32 As he reported to Rudolf Otto in a letter dated March 5, 1919. Husserl, Briefwechsel, band VII: Wissenschaftlerkorrespondenz, ed. K. Schuhmann (Dordrecht, 1994), 205-8.
} 
ambiguously, "I was raised in the Mosaic religion" [ich wurde in der mosaischen Religion erzogen]. ${ }^{33}$ On April 26, 1886, he converted to Christianity, becoming a baptized Evangelical Lutheran. The following year he married Malvine Charlotte Steinschneider, a fellow member of the Prossnitz Jewish community, daughter of the Jewish scholar Sigismund Steinschneider and a relative of the more well-known Moritz Steinschneider. She baptized before the wedding, too. It is significant that unlike some converts from Judaism, Husserl's conversion stemmed from solemn faith. Remaining a religious man his entire life, he considered himself a non-confessional, "free-Christian". And while he was philosophically unable to adhere to some of the traditional dogmas, Husserl grounded his philosophical vocation in unambiguous religious terms. In a letter from 1919 to his (Jewish) student Arnold Metzger, he wrote: "I still lived in an almost exclusive dedication to my theoretical work - even though the decisive influences, which drove me from mathematics to philosophy as my vocation, may lie in overpowering religious experiences and complete transformation. Indeed, the powerful effect of the New Testament on a 23 -year old gave rise to an impetus to discover the way to God and to a true life through a rigorous philosophical inquiry". ${ }^{34} \mathrm{He}$ insisted on the profoundly religious task of his philosophy. "The life of humans is nothing but a way to God", he remarked, and the aim of his philosophy is "to arrive at God without God'. But this 'atheological' phenomenological approach, he explained, is religiously charged, as it is intended "to pave the way to God for humans who do not have [...] the certainty of faith through the Church". 35

Taking these biographical facts into account, there is little surprise that Husserl was a debated figure in intellectual Jewish circles around the fin de siècle and in the early years of the twentieth century, with the backdrop of the Jewish efforts for equal rights in Germany. Importantly, part of the Jewish campaign for equality consisted of highlighting their loyalty and contribution to the general German culture. This was often demonstrated by the achievements of acclaimed figures of Jewish origin. The problem was, however, that since in the heart of this strategy for Jewish validation was an appeal to 'universal' standards that were also accepted by the non-Jewish public, it was often the case that the figures whose achievements were celebrated were highly assimilated Jews with little, if any, concrete ties to their Jewish heritage. Some had even converted to Christianity. This apparent inconsistency did

\footnotetext{
${ }^{33}$ Husserl, Briefwechsel, band VIII: Institutionelle Schreiben, ed. K. Schuhmann (Dordrecht, 1994), 235-37.

${ }^{34}$ In English: Husserl, “A Letter to Arnold Metzger”, Philosophische Forschung, 21 (1963): 48-68.

35 Adelgundis Jaegerschmidt, "Conversations with Edmund Husserl, 1931-1938”, New Yearbook for Phenomenology and Phenomenological Philosophy 1 (2001):331-50; Dermot Moran, Edmund Husserl: The Founder of Phenomenology, (Oxford, 2005), $16-8$.
} 
not go unnoticed, and debates raged in Jewish circles over whether it is legitimate, constructive, or desirable to position these figures as Jewish representatives. These debates turned ever more pressing as both German and Jewish nationalism were steadily on the rise, a fact that challenged, from opposing sides, the ideal of equality and integration. This was a paradoxical endeavor on another account, as it consisted of specifying the particularity and singularity of the Jews in order to support the cause of their 'normality'. Nevertheless, alongside the process of dissimilation that developed towards and throughout the 1920s, the tendency of 'taking stock' of Jewish loyalty and contribution continued, even as their conditions rapidly deteriorated. ${ }^{36}$

Husserl was among those whose innovations were either taken as an illustration of the Jewish contribution to German culture or as a manifestation of the plight of Jewish assimilation and selfalienation. We find, for example, "the logician, Husserl" included in an essay dedicated to a detailed list of Jews who influenced the development of contemporary psychology. ${ }^{37}$ In a report on Hitler's invasion of Czechoslovakia, Husserl was listed alongside Gustav Mahler, Sigmund Freud, and the novelist Franz Werfel as some of the Jewish "geniuses" who originated there. ${ }^{38} \mathrm{He}$ was also counted alongside the philosophers Hermann Cohen, Georg Simmel, and Ernst Cassirer, as well as a number of poets, to demonstrate the existence of "a Jewish community of arts and thought" in Germany. ${ }^{39}$ Likewise, Husserl's autograph was included in collection of prominent Jews' autographs and portraits established in the burgeoning National Library in Jerusalem in $1926 .{ }^{40}$

We also find various forms of negotiations concerning Husserl's identity. In the Jüdisches Lexikon, for example, Husserl - "the most influential founder of modern phenomenology" - was listed both in the entry "Philosophie, Juden in der" and in the entry "Taufjudentum". The ambiguity is found in the entry on Husserl himself - mistakenly recorded as 'Husserl, Eduard' - that concluded

\footnotetext{
36 The Nuremburg Laws seem to be the straw that broke the camel's back. One this entire period, see Jacob Boas, "Germany of Diaspora? German Jewry's Shifting Perceptions in the Nazi Era (1933-1938)", Leo Baeck Institute Year Book, vol. 27 , no. 1 (1982):108-26.

${ }^{37}$ H. Rudy "Die Juden in der Psychologie der Gegenwart", Gemeindeblatt der Israelitischen Gemeinde Frankfurt am Main, no. 2 (October 1931): 38.

${ }^{38}$ Felix Weltsch, "Sofa shel yahadut chekeslovakia”", Davar, May 4, $1939,2$.

${ }^{39}$ Rudolph Kayser, "Jüdische Gemeinschaft", no. 5, Neue jüdische Monatshefte (10.12.1917): 112.

40 Abraham Schwadron "Die Autographen- und Porträtsammlung der Jüdischen National- und Universitätsbibliothek im Jerusalem", Palästina, no. 6 (June 1935): 305-8.
} 
with the statement: "H[usserl] is no longer Jewish" [H. gehört dem J.-tum nicht mehr an]..$^{41}$ In another piece, Husserl, Henri Bergson and Georg Simmel were noted as counter examples to the claim that Hermann Cohen's thought is "typical of the Jewish mentality" and represents the Jewish Völkerpsychologie. ${ }^{42}$ He was culled again, alongside Albert Einstein and Freud, as a figure of Jewish origin who disputed "the conventional judgments" regarding the character of German and Jewish intellectuals. ${ }^{43}$ Similarly, in a Zionist reflection on the predicament of Jewish assimilation into German culture, Husserl was noted alongside Jakob Wassermann, Mahler, Cohen, and Simmel as representatives of a wider phenomenon of deeply assimilated Jews who are so immersed in the "German spirit" that they had essentially become its authentic exemplars. ${ }^{44}$ In an ensuing essay by the same author, Husserl was presented alongside Disraeli, Marx, Einstein, Bergson, Cohen and Simmel as negative examples of prime figures who had completely alienated themselves from their Jewish birthright. ${ }^{45}$ Husserl's conversion was also utilized to point attention to the worries of assimilation by Hugo Bergmann, the prominent philosophical figure in Palestine at the time. In a newspaper article prompted by the phenomenologist's passing, Bergmann offered an informative description of the development of Husserl's thought, concluding with the following remark:

"Husserl himself recounted that his path from mathematics to philosophy was determined by powerful religious experiences. The New Testament had a decisive impact on him when he was twenty-three, and this religious influence completely transformed him, turning him into a philosopher. Husserl dies as a Christian and will surely be buried in a Christian cemetery. He was born to an established community, k"k [acronym for kehilat kodesh, holy community] Promnitz. And only the New Testament left a religious impact on him. And as to us, who shall be blamed: him or us?"46

These examples illustrate the problematic of negotiating conflicting conceptions of ancestral, religious, national, and self-proclaimed identity so characteristic of the European modern Jewish experience. But perhaps the most telling case of the way in which the ambiguity around the status of Husserl's Jewishness was played out is found in an essay by Heinrich Berl, where he described his

\footnotetext{
41 Jüdisches Lexikon. ein ensyklopädisches Handbuch des jüdischen Wissens in vier Bänden, ed. G. Herlitz and B. Kirschner, vol. 4 (Berlin, 1927), 919, 888, 1701.

42 Gottfried Solomon, "Völkerpsychologie: Zur Kritik der Judentums”, Der Jude, vol. 5 no. 4 (1920-1921): 250.

${ }^{43}$ David Baumgardt, "Jüdische Gelehrtenköpfe”, Der Morgen, vol. 11 no. 1 (April 1935):11.

44 Arnold Zweig, "Jude und Europäer", Der Jude, vol. 2, no. 1-2 (1917-1918), 26.

45 Arnold Zweig, "Der heutige deutsche Antisemitismus", Der Jude, vol. 5 no. 4 (1919-1920): 199, and Der Jude, vol. 5 no. 11 (1919-1920): 627.

46 Hugo Bergmann, “Edmund Husserl”, Davar, May 13, 1938, 2 [Hebrew].
} 
personal impressions of a series of encounters with notable Jewish intellectuals and literati. ${ }^{47}$ That a 1929 encounter with the aging Husserl was included in this essay at all is in itself noteworthy, for by then he had lived as a faithful Christian for over four decades. Equally noteworthy is the title of the section describing the encounter: 'Edmund Husserl or the Judaization of Platonism' [Edmund Husserl oder Die Judaisierung des Platonismus]. "My impression was one of the best of my life”, Berl's narrated. "I sat opposite a hermit whose whole physiognomic betrayed nothing but thinking. Strange: his appearance did not seem actually Jewish to me. And yet his 'conceptual' visage ['begriffliche' Antlita] was somehow rabbinical, talmudistic". One may justifiably wonder what exactly is the 'Jewish' appearance that the author had expected to see, yet it is clear that Husserl's Jewishness was predetermined and that the gap between expectation and actuality is bridged by an obscure 'conceptual visage'. Berl described Husserl grumbling over the fact that the vast amount of ideas and materials he had collected over the years will hinder his ability to finish writing his philosophy, noting: "That was the Jewish thinker who spoke to me, not the Greek one, whom he would so much like to be. That was the Jewish boundlessness [Grenzenlosigkeit] from which he suffered”. The marking of Husserl's Jewishness was repeated also in the description of Berl's departure. "As I climbed down the stairs", he wrote, "I felt [...] that I had been with Ahasverus, who donned a Greek garb only for show". The overall impression conveyed by this report is that despite the desire to assimilate and become 'Greek', Husserl's Jewishness simply radiated from him. It is not external impediments, such as antisemitism or religious biases, that rendered assimilation a failure, but rather the inalienability of one's Jewishness. Husserl, clearly, was incognizant of this simple truth, but for Berl, the author, it was plainly apparent.

Wishing to convey the intensity of the encounter, Berl also reported Husserl's pain for having "lost my students"'. Commentating, Berl explained: "He probably means Scheler and Heidegger, both of whom turned to anthropology". But despite the philosophical discrepancy between Husserl and his rebellious students, the essay made clear that it is of secondary importance to a more fundamental distinction. In the section dedicated to Berl's encounter with Scheler (whose mother was Jewish and who was raised in an Orthodox Jewish home but later turned to Catholicism and eventually discarded all religious affiliation), Scheler is said to have complimented Heidegger's Sein und Zeit for being "one of the most important books", only to have then added, "Heidegger is of course affected by my

\footnotetext{
47 Heinrich Berl, "Begegnung mit Jüdischer Zeitgenosse: Bergson, Husserl, Scheler, Buber, Gundolf, Mombert, Wasserman”, Menorah: jüdisches Familienblatt für Wissenschaft, Kunst und Literatur, Vol. (1932), Issue 7-8 (July 1932): 317-35, 319-21. Berl, who was not a Jew, was deeply integrated in Jewish intellectual circles and a close friend of many Zionists.
} 
anthropology". Admitting to a mere cursory familiarity with Heidegger's work, Berl requested further clarification. Scheler retorted: "Heidegger is a static thinker, I am a more dynamic one. He feels closer to the Greeks, I feel closer to the Jewish prophets [Ihm liegen die Griechen näher, mir die jüdischen Propheten]". ${ }^{48}$ Notwithstanding its tenuous characterizations, this is an important utterance because it reveals that from the perspective of this essay, despite their diverging philosophical views and despite the fact that Scheler and Heidegger both turned away from Husserl and toward a similar direction, Husserl and Scheler nevertheless stood in opposition to Heidegger. For unlike him, they are both included under the category of "Jüdischer Zeitgenosse".

\section{Husserl: A Symbol of Jewish Misfortune}

Husserl's Jewish origin was thus central to the way in which he was discussed in Jewish contexts, and his differing depictions were harnessed ideologically and brought to bear some of the urgent issues confronting the European Jewish world at the time. We are now in place to explore how the Husserl-Heidegger relationship was imagined by Jews, and specifically, how it came to encapsulate wider cultural, political and intellectual issues.

As a famed philosopher, Husserl's downfall from the heights of the philosophical world to the gutters of segregation and neglect was taken notice of by many. But since it was spawned by anti-Semitic persecution, it resonated distinctly in Jewish circles in which such experiences were not foreign. In some recountings of the troubling events that unfolded in Freiburg University after the rise of Hitler, Husserl's fate became symbolic of the Jews' misfortune in Germany. One such interpretation was offered by Martin Buber in his 1938 lecture series Who is Man?. Buber listed two factors as main contributors to the maturation of the anthropological-existential problem in modern philosophy: the loss of the organic life-style of the past, and the triumph of technology and machines. In his mind, these two factors are linked to Husserl's philosophy and to what is judged as his uniquely GermanJewish tragedy.

"It [does not] seem to me to be chance that Edmund Husserl, the man in whose school and methods the most powerful attempts of our time to construct an independent philosophical anthropology made their appearance, was a German Jew, that is, the son of a people which experienced more grievously and fatefully than any other the first of those two factors, the increasing decay of the old organic forms of man's common life, and the pupil and adopted son, as he thought, of a people who experienced more grievously and fatefully than others the second of the two factors, man's lagging behind his works". 49

\footnotetext{
48 Berl, "Begegnung", 333.

${ }^{49}$ Martin Buber, "What is Man?, Between Man and Man, trans. R. G. Smith (London, 1947), 157-9.
} 
According to Buber's analysis, the encounter between Germans and Jews in the turbulent time in which they underwent and typified the processes of modernization fomented the conditions that brought about Husserl's philosophical innovations. It is worth asking whether Buber was in fact referring to Heidegger when he mentioned the attempt "to construct an independent philosophical anthropology" from within Husserl's "school and methods". But it is significant that Husserl is described as the 'son' of the Jews and the 'pupil and adopted son' of German culture and religion. The difference between the two is underscored by Buber's addition "as he thought" [ka'asher dima], hinting to the failure of Husserl's assimilation that was made manifest by the termination of his role by the Nazi decree. Regardless of the slacken explanatory power of Buber's postulation in making sense of Husserl's ideas, the emblematic features instilled into Husserl's personal and professional misfortune are apparent here. Husserl embodies the tragic unfolding of the German-Jewish encounter which Buber, having recently left Germany for Palestine, himself experienced first-hand.

A more explicit portrayal of Husserl as symbolic of the wider Jewish calamity was offered in Bergmann's 1935 work Hogey ha-dor. Here, too, Bergmann took note of the particularly Jewish dimension embedded in Husserl's misfortune:

"It was a particular tragedy - personal tragedy and part of our national tragedy as well - that this philosopher, who was born a Jew and abandoned his Judaism, who received the religious urge through Christian channels and who served German philosophy for his entire life, saw in his old age the destruction of the culture which he sought to rebuild".

Following this lamentation, Bergmann added: "One of his closest students, Martin Heidegger, became the philosopher of the German revolution of 1933 ". ${ }^{50}$ This is an early appearance of the typology of 'Husserl the Jew' versus 'Heidegger the Nazi' which would become central to their codepiction. In this passage Husserl is portrayed as the embodiment of the modern Jewish predicament. No one manifested the shattered dream of modernity and the inescapability of the Jewish fate more than Husserl, whose quality of contribution to and depth of immersion in German culture and religion was unmatched, but who still suffered the abuse of anti-Jewish legislation. Husserl's "personal tragedy" reflects the "national tragedy": the rise and fall of Husserl serves as a symbol of the hope and disillusionment from the promise of Jewish emancipation and equality in Germany.

Although its political bearings are implied, Bergmann does not straightforwardly politicize Husserl's plight. A more palpable politicization is offered in a 1938 memoriam essay to Husserl by Hans Jonas - signed under his Hebrew name, Jo@hanan' - who received the news of the phenomenologist's passing while in Palestine. Jonas studied under both Heidegger and Husserl in the

\footnotetext{
${ }^{50}$ Bergmann, Hogey ha-dor, 121.
} 
universities of Freiburg and Marburg in the 1920s. His groundbreaking doctorate on Gnosticism was written under Heidegger's supervision and substantively drew on the conceptuality of Sein und Zeits existential analytic. After Heidegger joined the Nazi party, a disheartened Jonas broke ties with his Doktorvater. ${ }^{51}$ Jonas's essay was originally a memorial-lecture for Husserl delivered at the Hebrew University and broadcasted over the radio. The majority of the address was a summary of the trajectory of Husserl's thought and its key ideas. Appropriately, it praised Husserl's philosophical achievements and the impact he had had on his students and the philosophical world as a whole. Here, too, Husserl's personal fate was contextualized with the Jewish crisis in Europe and described as emblematic of the contemporary Jewish condition. Jonas proclaimed:

"He educated an entire generation to thought and inquiry and enjoyed fame and glory, but he died stranded and alone in a radically altered world; it is even forbidden to eulogize him there. In response to the pact of silence in the country in which he advanced his teachings throughout his entire life, we ourselves see it as our honoured duty to pay tribute to him here. Husserl, who had left Judaism in his youthful years, was a German professor who felt entirely like a servant of European science, like a guardian of the heritage of Western culture, would have certainly never thought that what would be done in Jerusalem would not be done in Freiburg. The fact that today a student who had sat years ago at his feet could speak about his thought from a Jerusalem transmitter in the Hebrew language is in itself a symbol of our time". ${ }^{52}$

When, five years after Hitler's rise to power, Jonas spoke of Germany's betrayal of Husserl, he was referring to the betrayal of European scientific life and the 'heritage of Western culture'. He was, moreover, telling the tale of Germany's betrayal of its Jews. The abuse of a radically assimilated and self-alienated Jew who seemingly successfully integrated into European culture represented like no other the refusal of Jewish existence in Germany. Jonas's retelling is overtly politicized: Husserl's personal fate symbolizes the collapse of the inclusive vision of European scientific life and by implication, also of the rejection of its Jewish contribution. In a self-reflective moment, Jonas even inserted his obituary into this symbolism. For while there was a "pact of silence" in Germany regarding Husserl's passing, the philosopher was not forgotten by his brethren in the fledgling Jewish intellectual community in Palestine, where Jonas believed the European scientific ethos would be continued.

\footnotetext{
51 On Jonas's time in Marburg and his relation to Heidegger, see Hans Jonas, Erinnerungen, ed. C. Wiese (Frankfurt am Main, 2003), 108-28; Steven Wasserstrom, "Hans Jonas in Marburg: 1928", Judaism and the Phenomenon of Life: The Legacy of Hans Jonas - Historical and Philosophical Studies, ed. H. Tirosh-Samuelson and C. Wiese (Leiden, 2008) 39-72. For a recent analysis of Jonas's philosophical positioning vis-à-vis Heidegger and Husserl, see Elad Lapidot "Geschichtsphilosophische Einleitung”, in: Kritische Gesamtausgabe der Werke von Hans Jonas, Band IV/1, Gnosis und spätantiker Geist, hg. von E. Lapidot und R. Kampling, Freiburg/Berlin/Wien 2018 (forthcoming).

52 Jo@hanan (Hans) Jonas, "Edmund Husserl”, vol. 21, Turim, September 7, 1938, 2 [Hebrew]. The address was given on June 14, 1938 and was preceded by a few words from Buber.
} 
Transmitted from Jerusalem and in Hebrew, the obituary was itself a gesture implementing the 'moral' of Husserl's story: Zionism.

While Jonas's attribute was detailed and moving, not everyone was happy with the public appraisal of Husserl. The following week, Shoshana Sharira, a member of the editorial board of the Ha-boker newspaper, the organ of the center-right movement and political party The General Zionists in Palestine, expressed her dismay over the public tribute to the apostate Jew in the newspaper. "Has our sense of self-respect really become so dull?", she wrote,

"Husserl was of course an important philosopher, and in the history of philosophy one cannot pass over him in silence. But to hold for this man, who was a wilful apostate [mumar mida'at], a memorial service after his death, even in the form of a lecture, is certainly uncalled for. Since when do Jews organize eulogies for apostates, even if they were the greatest of the greatest? And how odd was it to read the announcement in the newspapers about the address in the radio dedicated to the deceased 'the Professor Husserl z"l" [acronym: qichrono livracha, "of blessed memory']. Since when is it accustomed to write z"l for an apostate?"53

\section{Succession and Discontinuity, Culture and Barbarianism}

The dispute over the appropriate attitude towards an apostate Jew notwithstanding, the concluding paragraph of Jonas's address is worthy of attention. Husserl, it is stated, was "an enthusiastic thinker who was entirely dedicated to thought. In the present day, which is increasingly becoming [a time of] a multitude of muddled views, blind faith, and ignorant prattle - in these times Husserl was like a purifying and welding fire”. In keeping with the aforementioned passage, this concluding statement featured a common way in which Husserl's philosophy was conceptualized visà-vis Heidegger's, in non-Jewish and Jewish discourses alike, namely, through the contrast between rationalism, strict scientific method, and humanism, and the growing sense of violent antiintellectualism and irrationalism permeating culture and politics. Bergmann, for example, in a review of new works of philosophy from 1933-34, described the contemporary philosophical scene in Germany as "in a state of decay". While before the Great War there were a number of schools presiding over philosophical world, he wrote, after the war Husserl's phenomenological school eclipsed the others and became dominant. Quickly, however, "it collapsed from within, as there is no greater abyss than the one between Husserl the teacher and Heidegger the student". 54 A year earlier, Josef Schächter, an ordained rabbi, philosopher, and former member of the Vienna circle who wrote his dissertation under Moritz Schlick, presented the discrepancy between the two philosophers in

\footnotetext{
53 Shoshana Sharira, "Sheelot ha-shaa be-yerushalaim”, Ha-boker, 22 June, 1938, 5.

54 Hugo Bergmann, “Sefarim philosophim @hadashim”, Moznaim, 1, 3 (1933-34): 76-9.
} 
terms of their adherence to reason. "Anyone who understands anything", he wrote in a review of Husserl's phenomenology, "knows to differentiate between Husserl and his students, since his students are nothing like him. Scheler, Hartmann and Hedegger [sic], who are widely influential in phenomenologists' circles, do not possess the logic and profundity of Husserl. They are inclined to different metaphysical systems, but the latter in particular has no connection whatsoever to anything logical or to pure thought". ${ }^{5}$

Jonas rehearsed this point in another commemorative essay, where he referred to Husserl as "the last in the lineage of greats" who devoted themselves to the rational philosophical inquiry. Husserl was "today's supreme embodiment of the rational consciousness of Western thought". ${ }^{5}$ This essay, like the eulogy, was a tribute to Husserl, but it was also a lamentation over the honorable intellectual tradition celebrating culture, morality, and the rigorous investigations of philosophy which with Husserl's death had purportedly come to a close. With his words, Jonas gave voice to the allencompassing atmosphere of crisis that inserted an urgency into theoretical debates dramatically exceeding the tensions of standard intellectual discourse. Philosophical disputes staged the battle over the very character and fate of the West's legacy. Consequently, the philosophical differences between Husserl and Heidegger amounted to more than a bitter disagreement between thinkers of diverging temperament, and the transition from the one to the other was more than a generational shift in intellectual taste. It signified, rather, the difference between culture and vulgarity, morality and nihilism - and Heidegger's association with the Nazi party cemented this schematization. This can be observed, for example, in a number of Levinas's early writings, where the philosophical differences between Husserl and Heidegger are implicitly politicized along similar lines. ${ }^{57}$ Indeed, for some, since Husserl's successor did not only shun the path of reason but also publicly associated himself with barbarianism, Husserl's death represented the smothering of the final flame of Western civilization.

It is important to note at this point that while widespread, the reduction of Heidegger's political stance to his attitude towards reason is predicated on a misconceived correlation between the advocation of rationalism and dovish politics, and contrarily, between the de-prioritization of reason

\footnotetext{
55 Josef Schächter "Phenomenologia ve-higayon”, Moznaim 1, 4 (1933): 59-67.

${ }^{56}$ Hans Jonas, "Edmund Husserl ve-hashe'ela ha-ontologit”, Moznaim, 7, 41 (1938): 581-9. Published in English as "Edmund Husserl and the Ontological Question", Études phénomenologiques 17 (2001): 5-20

${ }^{57}$ Samuel Moyn, "Judaism against Paganism: Emmanuel Levinas's Response to Heidegger and Nazism is the 1930s", History and Memory, 10, 1 (1998): 25-58.
} 
and reactionary totalitarian politics. ${ }^{5}$ Conceptually, this correlation has been dismantled already by Max Horkheimer and Theodor Adorno in their 1947 study Dialectic of Enlightenment, and repeatedly ever since. Empirically, moreover, this schematization simply did not reflect the political sidings of German intellectuals at the time, when supporters and dissenters of Hitler cut across the philosophical spectrum. ${ }^{59}$ In addition, the axis of rationalism-irrationalism is somewhat misplaced in the context of Heidegger, for whom the notions of immediacy and derivativeness are more operational. Unlike the claims of his detractors, he did not advocate 'irrationalism' and was not against reason, although he did reject positions vouching for its ultimate supremacy.

Had philosophy reached an impasse with Husserl's death and the exposure of Heidegger's political association? What does the future hold in store for philosophy, for culture? A pinch of the perplexity of the time is captured in a commemorating article to Husserl by Yisrael Zemora, a renowned literary critic and editor in Palestine. "A few years ago", he recounted, "the names Husserl and Heidegger were almost always uttered together, and indeed they had a weird relationship of father and son, master and pupil, friendship as well as mutual rivalry”. However, in 1933, Zemora narrated, Husserl's life took a fateful turn:

"In that university Heidegger served as the professor of philosophy. Many say he is the greatest German philosopher of our time. Heidegger was Husserl's student. Many of those who came to Freiburg to study under Husserl [latseket maim al yadey Husserl] ended up studying under his great student [yatskum al yadey talmido ha-gadol. Heidegger never denied Husserl's impact on his own thought, and in his Sein und Zeit he explicitly notes Husserl as the source of his work. He quotes him regularly and dedicates the book to him. But Heidegger was close to the National Socialist movement even before Hitler's ascent to power (indeed, some facts are not easily explained!). And when in the year 1933 the teacher was ousted from his academic post (because of his Jewish origin), the student did not utter a word in his defense. There is, alas, nothing unusual in the staging and enacting of the drama of this expelling, yet seemingly, one of its main characters did not belong in such a scene. Heidegger! This is indeed perplexing but time will tell. And now the news of Husserl's death. The telegram has arrived from Berlin. Another one of science's greats has passed away. It seems as if a grim sickle is reaping the fields of science these days: they are dying one after the other, but who will come in their place? There is one in Germany, Martin Heidegger, who could have, possibly, filled the void of the deceased [and] continued his project - but he too is among the betraying priests [Ha'kohanim shebagdu]". ${ }^{60}$

\footnotetext{
58 Even Husserl and Heidegger were taken by it. See for example, Heidegger, "Hönigswald aus der Schule des Neukantianismus", letter dated June 25, 1933, in GA 16: 132-3; Husserl, Crisis of the European Sciences and Transcendental Phenomenology: An Introduction to Phenomenological Philosophy (Evanston, 1970).

${ }^{59}$ Hans Sluga, Heidegger's Crisis: Philosophy and Politics in Nazi Germany (Cambridge, Mass., 1993).

${ }^{60}$ Yisrael Zemora, “Tur rishon”, Turim, 22, May 11, 1938, 1.
} 
In this passage we see that Husserl is taken to represent the ethos of Wissenschaft and Heidegger's personal betrayal of Husserl is interlinked with his betrayal of the spirit of philosophy and science. It also illustrates the bafflement caused by Heidegger's political views and mistreatment of Husserl. How can a philosopher, the bearer of light and lover of truth, hold those views and act in such a manner? The supersession of Husserl by Heidegger was a Jewish tragedy not only because the persecution of the former for being a Jew was "appropriate to the spirit of the times", as Zemora wrote, but because it reflected the decay of the European spirit and ethos upon which Judaism has left its undeniable mark. Indeed, the Jewish poet Jacob Fichman spoke for many when he wrote that Hitlerism "sentenced extinction to spirit, which is, of course, a 'Jewish' force", although it is "not only a war against Judaism, but also against the lucidity of Greece, against the Western foundation, upon which European culture was established”. Likely hinting to Heidegger, Fichman added that the Nazi war on culture, reason and morality is buttressed by "a decent number of reason-hating philosophers". ${ }^{61}$ In this way, the German betrayal of the Jews was also self-betrayal, for they together, Jews and Germans, Athens and Jerusalem, are the paragons of Western spirit.

\section{Judaism of Reason versus Nazism}

In the Jewish imagination, the framing of the contrast between Husserl and Heidegger through the prism of rationalism and irrationalism was particularly luring, since for many at the time the bond between Judaism and reason was a fundamental element of their identity. While the early decades of the twentieth century oversaw the decline of the convergence of the values of the enlightenment and Judaism, many Jews subscribed to the view that Judaism was a religion of reason and that the biblical prophets proclaimed a universal ethical message in the spirit of Kant. For them, Heidegger's rejection of Husserl's philosophy and the values underpinning it - not unlike his critique of neo-Kantianism was more than an erroneous philosophical stance; it was an assault on the foundations of Judaism as they understood it. From this perspective, Heidegger's public support of National Socialism confirmed the anti-Jewish impulses embedded in his philosophy. One noted articulator of this view was Ernst Cassirer, who in his The Myth of the State evoked the disparity between Husserl, whose "highest aim was to make philosophy an 'exact science', to found it on unshakable facts and indisputable principles", and Heidegger, for whom "such a tendency is entirely alien". ${ }^{2}$ In a later chapter in this work, Cassirer fleshed out what he took to be the ties between Heidegger's political views and his

\footnotetext{
${ }^{61}$ Fichman, "Mil@hama al ha-tvuna”, Moznaim 6 (1934): 4-5.

${ }^{62}$ Ernst Cassirer, The Myth of the State (London, 1946), 292-3.
} 
rejection of reason. Heidegger, he declared, is one of the intellectual expressions of the modern reemergence of myth in the political sphere, the most demonic of which was Nazism. Cassirer also explicitly tied Heidegger's politics with his objection to Husserl's ethos of reason, objectivity, and logic. In this way, despite some non-negligible differences between (his unorthodox version of) neoKantianism and Husserl's phenomenology, Cassirer drew Husserl into his own philosophical camp, widely conceived, over against Heidegger's irrationalism. ${ }^{63}$ This, it should be noted, is not disconnected to Cassirer's conceptualization of Judaism, as in a contemporaneous essay, "Judaism and Modern Political Myths" (1944), he developed this thought and opposed the politics of mythical irrationality with his vision of a Bildungsliberalismus from the sources of Judaism. ${ }^{64}$ Reflecting the majority-view of the progressively-leaning liberal German Jewry at the time, Cassirer, following Hermann Cohen, claimed that only the mythosfrei ethical monotheism of the biblical prophets could stand as a bulwark against the violent tide of myth currently threatening to destruct western civilization, a tide for which Heidegger was a central spokesman.

With the prevalence of the rationalism/non-rationalism axis and as part of the present-day debates between neo-Kantianism, phenomenology, and the so-called existence-philosophy, others framed the Husserl-Heidegger-Judaism constellation differently. For example, Ludwig Feuchtwanger followed Julius Kraft's critique of phenomenology as a fundamentally intuitionalist and irrational endeavor, and as such, associated with authoritarian politics. In a review of Kraft's Von Husserl zu Heidegger: Kritik derphänomenologischen Philosophie (1932), Feuchtwanger lauded Kraft for his "productive critique of Heidegger's pseudo-philosophy" and its misleading "appearance of philosophical profundity". A respected intellectual figure in German-Jewish circles and a man of Jewish-Orthodox upbringing, Feuchtwanger also agreed with Kraft's critique of phenomenology, be it Husserlian or Heideggerian. According to this view, Husserl leads to Heidegger: "The development of the phenomenological school began with Husserl's call for philosophy as rigorous science and ended with Heidegger's metaphysics (which expressively renounces scientific philosophy)". ${ }^{55}$ This explains Heidegger's association with "our whole 'intellectual' National Socialism and Noble-Anti-Semitism". "This existence philosophy", it is added, is linked to "the new theories concerning suspending the state-law" of Carl Schmitt, who was also linked to Nazi ideology. In another piece by Feuchtwanger,

\footnotetext{
${ }^{3}$ Cf. for example Fritz Kaufmann, "Cassirer, Neo Kantianism, and Phenomenology", The Philosophy of Ernst Cassirer, ed. Paul Schilpp (Evanston, Ill.: The Library of Living Philosophers Inc., 1949), 799-854.

${ }^{64}$ Cassirer, "Judaism and the Modern Political Myths", Contemporary Jewish Record, 7 (1944) 115-26.

${ }^{65}$ Ludwig Feuchtwanger, Review of "Julius Kraft, Von Husserl qu Heidegger: Kritik der phänomenologischen Philosophie", Bayerischen Israelitische Gemeindezeitung, 19 (Oct. 19 1932): 298-9.
} 
in which he took sides with Cassirer in the famous 1929 encounter with Heidegger at Davos, Heidegger is mentioned in the same breath with another intellectual proponent of National Socialism, when "the false lights of Seins- und Lebensphilosophie, whether drawn from Klages or Heidegger" are repudiated. ${ }^{66}$ The philosophical grounding of Heidegger's repugnant political affiliation lay in his irrational phenomenology. As such, phenomenology - Husserl's and Heidegger's - is antithetical to Judaism, and its rise to prominence testifies to the ominous current philosophical and religious state of affairs.

We find a similar conceptualization expounded by Joseph D. Soloveitchik, who was allegedly present in a lecture by Heidegger during his years in Berlin as a philosophy doctoral student. ${ }^{67}$ In his 1941 Halakbic Man, Soloveitchik attacked "the entire Romantic aspiration to escape from the domain of knowledge, the rebellion against the authority of objective, scientific cognition" that Heidegger's philosophy bore witness to. ${ }^{68}$ Over against these "Dionysian" tendencies that have presently "brought complete chaos and human depravity to the world", Soloveitchik posited a model of Judaism marked by reason and morality. Three years later, in his 1944 Halakhic Mind, he rehearsed Kraft's critique of phenomenology as mysticism and the neo-Kantian critique that the phenomenological devotion to the prescientific experience leads to subjectivism and thus constituted an infringement on the impartiality of rational inquiry. On this account, not contrast but continuity marked the philosophical development from Husserl to Heidegger. Once again linking philosophical assumptions to political affiliation, and unmistakably hinting to Heidegger, Soloveitchik commented: "It is no mere coincidence that the most celebrated philosophers of the third Reich were outstanding disciples of Husserl. Husserl's intuitionism (Wesensschau), which Husserl, a trained mathematician, strived to keep on the level of mathematical intuition, was transposed into emotional approach to reality. When reason surrenders its supremacy to dark, equivocal emotions, no dam is able to stem the rising tide of the effective stream". ${ }^{99}$ For Soloveitchik, as for Feuchtwanger, the two phenomenologists were unequal in their devotion to irrationalism, but they were equally guilty of insufficient fidelity to reason. And given the dire political implications of such infidelity, both were opponents of a Judaism of reason

\footnotetext{
${ }^{66}$ Peter E. Gordon, Continental Divide: Heidegger, Cassirer, Davos (Cambridge, Mass., 2010), 298.

${ }^{67}$ The following testimony has been recorded in the name of Soloveitchik: "I was in Heidegger's class. I was a good student. He continually spoke about human destiny, spiritual perceptions, and the events of that time." Aaron RakeffetRothkoff, The Rav: The World of Rabbi Joseph B. Soloveitchik, vol. 1, (New Jersey, 1999), 195. Another testimony is provided by Rabbi Zev Gotthold, who claims that Soloveitchik mentioned the difficulty of Heidegger's Sein und Zeit in a conversation with him. See Murray Johnston, Engagement and Dialogue: Pluralism in the Thought of Joseph B. Soloveitchik (Masters Thesis, Department of Jewish Studies, McGill University, 1999), 119-24, 126-31.

${ }^{68}$ Joseph B. Soloveitchik, Halakbic Man, trans. L. Kaplan (Philadelphia, 1983), 141 n 4.

${ }^{69}$ Soloveitchik, The Halakhic Mind, (New York, 1986), 53.
} 
and were either directly or indirectly complicit in the Nazi crimes. Unlike Cassirer, according to this Neo-Kantian depiction the transition from Husserl to Heidegger reflects the deepening deterioration of the status of reason and the strengthening of forces antithetical to Judaism. ${ }^{70}$ Moreover, unlike the disregard of philosophical content and the underscoring of ethnic roots in Heinrich Berl's distinction between Heidegger, and Scheler and Husserl, Feuchtwanger and Soloveitchik focused principally on philosophical content in their conceptualization of Husserl's and Heidegger's philosophical bearings on Judaism.

\section{Post-War Perspectives}

Understandably, the new information about the Nazi crimes and Heidegger's political misconduct which came to light after the war fed into the already available typological structures governing the way in which the Husserl-Heidegger relation was imagined, albeit with a different resonance. It is, for example, rare to find a discussion of either philosophers written for a primarily Jewish readership in which Heidegger's Nazism or Husserl's Jewish origins are not mentioned. One case in which this is discernable is the 1968 translation of Heidegger's essay “Origin of the Work of Art" into Hebrew by Shlomo Zemach. ${ }^{71}$ This translation appeared - uncoincidentally - in the wake of a number of momentous events pertaining to the relations between Germany and Israel after the holocaust, such as the Eichmann affair (1960-62), the ensuing 'Arendt controversy', and the establishment of diplomatic relations with the Federal Republic of Germany (1965). In an early draft of an appendix to the translation, Zemach described Heidegger's post-1933 relationship to Husserl, “who was an apostate Jew”. After mentioning Heidegger's support for the Nazis, Zemach related:

"The situation became so, that when the new rulers began to harass the old and sick Husserl, Heidegger did nothing in his aid and did not persuade the persecutors to leave his teacher and mentor alone. If it were not for some faithful friends who helped Husserl out of Germany and transported him secretly to a monastery in Belgium, he surely would not have died a natural death; certainly his soul would have departed in one of the extermination camps in Germany". ${ }^{72}$

\footnotetext{
${ }^{70}$ In a belated memorial essay, Lev Shestov frames Husserl in contrast to Kierkegaard: the former seeks the absolute truth in reason, while the latter seeks it in faith - and never the twine shall meet. In Shestov's rigid distinction between Athens and Jerusalem, Husserl, the adherer of reason, falls sternly on the side of the Greeks, in opposition to the Bible and the world of faith. Interestingly, Heidegger goes unmentioned in this essay. Leon Shestov, "In Memory of a Great Philosopher: Edmund Husserl”, Philosophy and Phenomenological Research, 22, 4 (Jun. 1962): 449-471.

71 Martin Heidegger, Mekoro shel ma'ase ha-omanut, trans. S. Zemach, (Tel Aviv, 1968). On this episode see Daniel Herskowitz, "Heidegger in Hebrew: Translation, Politics, Reconciliation”, New German Critique 135, 3 (2018): 97-128.

72 The drafts are found in the file titled 'Shonot', call number 52, in Shlomo Zemach's papers in the Gnazim Archive, Tel Aviv.
} 
There are a number of inaccuracies in this passage: Husserl had died before the outbreak of the war; it was not Husserl who was smuggled to Belgium, but rather his papers and library; and it was not his close friends who orchestrated the smuggling but rather the Franciscan priest Herman Van Breda (and moreover, all the Nazi death camps were located outside Germany). ${ }^{73}$ These imprecisions may explain why this passage was deleted from the following drafts of the appendix - though the evocation of Husserl's apostacy remained and appeared in the published version. Yet the narrative conveyed in the passage, in a clear post-holocaust register, betrays an unmistakable solidarity with Husserl, who as a Jew was potentially a victim of the holocaust. In the various reviews of Zemach's translation, Heidegger's Nazism as well as Husserl's Jewish origin were repeatedly highlighted. ${ }^{74}$

Familiar structures also informed Hans Jonas' 1963 lecture "Husserl und Heidegger", dedicated to his philosophical impressions and personal memories of the two philosophers. ${ }^{75}$ In this lecture Jonas offered a concise outline of Husserl's phenomenology and some impressions of his personality, and then turned to Heidegger to do the same, effectively described him as the mirror image of his teacher. In terms of their personal relations, Jonas related that Husserl "loved him" Heidegger - "like a son", although he wrongly believed that Heidegger was the student who would continue his life's work. He also elaborated on Heidegger's mistreatment and absence from Husserl funeral, as well as on his Nazism. Significantly, Jonas cited the opening paragraph of his memorial address from Jerusalem and affirmatively repeated its Zionist conclusion, demonstrating that almost three decades later, he continued to believe that the breakdown of the Husserl-Heidegger moment bore wider cultural and political import for the Jewish world.

Indeed, Jonas seems to make a special effort to highlight Husserl's Jewishness in this lecture, even though he knew first-hand how minimal a role Jewish heritage played in Husserl's personal life. In a later interview Jonas recalled his time as Husserl's student and noted that for the great phenomenologist, "the membership in a Jewish student organization" - Jonas was then involved in Zionist activities - "was tantamount to Orthodoxy. I was, therefore, a Jew defined by faith, and that

\footnotetext{
${ }^{73}$ On the salvaging of Husserl's papers and the establishment of the Husserl archive in the Higher Institute of Philosophy in Leuven, Belgium, see H. L. Van Breda, "The Rescue of Husserl's Nachlass and the Founding of the Husserl Archives", trans. D. Ulrichs and B. Vassilicos, Geschichte des Husserl-Archivs/History of the Husserl-Archiv (Dordrecht, 2007), 39-69.

74 See for example, Reuben Rabinovitch, "Mishnato ha-estetit shel Heidegger", Moznaim 28 no. 2 (1969):132-134; Jo@hanan Arnon, "Martin Heidegger - be ivrit?!”, Hayom, October 18, 1968, 5; Hugo S. Bergmann, "Heidegger in hebräischem Gewande", Israelitisches Wochenblatt für die Schweiz (IW), December 6, 1968, 53, 55; Yoram Bronowski, "Hamilim ha-@hoshvot”,La-mer@hav,October 11,1968,6.

75 Published as Hans Jonas, "Husserl und Heidegger", in Herausforderungen und Profile: Jüdisch-deutscher Geist in der Zeit-gegen die Zeit, hg. Von S. Lalla, F. Preußger und D. Böhler (Freiburg i.Br./Berlin/Wien, 2013), 205-24, 429-30.
} 
was incompatible with philosophy". ${ }^{76}$ In this lecture, however, Husserl's complete ignorance of matters Jewish was interpreted paradoxically as confirmation of his Jewishness. Jonas informed that there was "something Jewish in his complete foreignness to everything Jewish" and that this "was unmistakable". He goes on to divulge that "In [Husserl's] Göttingen period that preceded the Freiburg period, he was called by his students 'the Rabbi from Göttingen”'. Similarly, in this lecture Jonas claimed that Husserl's conception of philosophy's moral ideal of self-justification and absolute selfresponsibility is grounded in a particular Jewish (or Jewish-Christian) motif.

What is most interesting about Jonas's relation to his two teachers is that while ostensibly taking the side of Husserl in 1938 and again in 1963, it is nevertheless the case that he recognized Husserl was no longer a compelling philosophical option after the advent of Heidegger. Indeed, the 'typological' structures governing his depiction of his former teachers ultimately stood in tension to his evaluation of their philosophy. As he wrote to Günter Anders upon Heidegger's passing: "Now Heidegger too has died [...] Whatever lay between us and was not forgotten - he was the great teaching and philosophically driving force in my life (Husserl entirely pales beside him) and also, as I believe, a real event in the history of thought. The latter can, of course, be disputed, but not the former". ${ }^{77}$ Indeed, Jonas's entire intellectual career can be seen as a dialectic of attraction and repulsion with regards to Heidegger. In this respect, Jonas is an example of host of intellectuals who were Jews - the names of Levinas, Strauss, Arendt, and Marcuse immediately come to mind - who were dissatisfied with the general framework of 'old thinking' but whose criticism of Heidegger came alongside the disturbing recognition of the profundity of his thought. Buber, too, judged that it was Heidegger who "undoubtedly belongs to the historical rank of philosophers in the proper sense of the term", deserving to be mentioned in "the same breath" with Kant and Hegel. ${ }^{78}$ Indeed, it can be said that while 'typologically' the favor may often lay with Husserl, there is little doubt that philosophically, it

\footnotetext{
${ }^{76}$ Interview with Hans Jonas, in Herlinde Koelbl, Jüdische Portraits: Photographien und Interviews (Frankfurt am Main, 1998), 171. Quoted in Wiese, Jewish Dimensions, 5.

77 Quoted in Wiese, Jewish Dimensions, 208n5. See also Jonas, Erinnerungen, 299-309; Idem, “Heidegger's Resoluteness and Resolve: An Interview”, in Martin Heidegger and National Socialism, ed. G. Neske and E. Kettering (New York, 1990$)$, $197-$ 203. The literature on Jonas and Heidegger is constantly growing. See for example Benjamin Lazier, God Interrupted. Heresy and the European Imagination Between the World Wars (Princeton, 2008) 27-59; Christian Wiese, “Revolt Against Escapism': Hans Jonas's Response to Martin Heidegger”, in Heidegger's Jewish Followers: Essays on Hannah Arendt, Leo Strauss, Hans Jonas, and Emmanuel Levinas, ed. S. Fleischacker (Pittsburgh, 2008); Eric Jakob, Martin Heidegger und Hans Jonas. Die Metaphysik der Subjektivität und die Krise der technologischen Zivilisation (Tübingen, 1996); Micha Brumlik, Die Gnostiker. Der Traum von der Selbsterlösung des Menschen (Frankfurt am Main, 1992), 312-69.

${ }_{78}$ Buber, "Religion and Modern Thinking" in Eclipse of God (New York: Harper \& Row, 1965), 70; Hans A. FischerBarnicol, "Spiegelungen-Vermittlungen", Erinnerung an Martin Heidegger, edited by Günther Naske (Pfullingen: Naske, 1977), 91.
} 
is the innovations and challenges put forth by Heidegger that have left an indelible mark on twentieth century European Jewish thought.

\section{Coda}

This article has dealt with an unacknowledged aspect of the Jewish reception of the HusserlHeidegger relation. It has traced a variety of ways in which Jews imagined this vexed relationship and argued that it functioned as a means for articulating ideological commitments regarding Judaism and Jewishness. While these articulations often rely on a set of somewhat unsatisfactory typological structures, they offer a portal into major concerns in twentieth century European Jewish existence and thought. Indeed, the Husserl-Heidegger episode served as a site upon which central challenges of modern European Jewish existence were projected. Since I have focused primarily on the period between the time of the relationship's commencement to around the 'second wave' of reactions to Heidegger's political lapse in the 1960s, I wish to present, in place of a conclusion, one unknown response to the publication of Heidegger's famous Der Spiegel interview from around the 'third wave', which sheds light on the present theme.

Yeshayahu Leibowitz, the Riga-born Israeli chemist and public intellectual, is a seemingly unlikely figure to offer a perspective on this episode. But his personal papers, kept at the Israel National Library in Jerusalem, testify to the little-known fact that he cultivated a keen interest in Heidegger. ${ }^{79}$ A file in Leibowitz's archive, entitled "Heidegger", holds tens of press-clippings, notes, and newspaper articles on Heidegger's philosophy and politics, in Hebrew, German, English and French. These include a copy of the Der Spiegel interview, marked by Leibowitz's handwritten comments. It also appears that he paid particular attention to the wave of debates over Heidegger's ties to the Nazi regime spawned by the publication of the Chilean historian Victor Farias's sensational book, Heidegger et le nazisme in $1987 .{ }^{80}$ In the context of the present essay, the following exchange, found in Leibowitz's papers, is of interest. In a small article, published in the Israeli newspaper Haaretz on June 13, 1976, Professor Gershon Weiler, the recently appointed head of the Philosophy Department in Tel Aviv University, rehearsed the tale about Heidegger refusing Husserl entry into the University library. He then added a less-known anecdote, that Gilbert Ryle, the renowned English philosopher and Weiler's mentor from his student days at Oxford, refused to shake Heidegger's hand when they

\footnotetext{
79 The Archive of Yeshayahu Leibowitz, ARC.4*1889 02 249, AC-0827, Israel National Library, Jerusalem.

${ }^{80}$ In English: Victor Farias, Heidegger and Nazism, trans. G. R. Ricci (Philadelphia, 1989).
} 
met because of the latter's treatment of Husserl. In response to this newspaper article, Leibowitz wrote that day to Weiler:

\section{"Dear Professor Weiler,}

Regarding the Heidegger-Husserl affair, see the interview by the editors of the weekly Der Spiegel with Heidegger in 1966 that was recently published, after Heidegger's death, on 31.5.76 (Heidegger forbade the publication in his lifetime). Apparently, the story about Husserl and the library is not true, but nevertheless Heidegger's disgracefulness [klono] is revealed in this interview. For us, as Jews - is not the apostate [meshumad] Husserl more despicable [nivee] than his student, the kosher goy?

Sincerely, Y. L.”

Wieler responded two days later:

"Dear Professor Leibowitz,

Thank you for your letter about Heidegger. Of course, I did not say that I am responsible for the accuracy of the story about the library, only that I heard it from Ryle - which I did. As to the remainder of your letter - indeed, there is an abyss between us, and due to the respect I have always had for you, please allow me not to elaborate.

Best wishes, Gershon Weiler”.

The striking point in Leibowitz's letter (which warrants a more detailed examination than space here permits) is that he considered Husserl to be more despicable than Heidegger. It can be said that from his perspective, the most significant betrayal to occur in this episode is not Heidegger's betrayal of his mentor, but Husserl's betrayal of his personal commitment as a Jew to Jewish law. Thus Husserl's conversion to Christianity appears to be worse than Heidegger's political involvement. ${ }^{81}$ Also curious is Leibowitz's claim that Heidegger was "a kosher goy" while at the same time speaking of his "disgracefulness". Perhaps rendering Heidegger as a "kosher goy" is intended rhetorically to accentuate through contrast Husserl's repugnance. Be it as it may, Weiler's refusal to respond ad rem reflects, no doubt, his reservations about Leibowitz's point. It is clear, however, that while Leibowitz reversed the common judgment of the two phenomenologists, for him, too, the relationship between them was not a mere teacher-student relationship turned sour. Instead, Heidegger was a goy, Husserl a Jew, and from his perspective - and as he indicated to Weiler, from their shared perspective as Jews - that was what was most important.

${ }^{81}$ Cf. to Strauss, "Philosophy as Rigorous Science", 31, where he dismisses a claim he had heard to the effect that the equivalence of Heidegger's political misconduct is Husserl's conversion to Christianity. 